\title{
MATTER AND MATTERING: \\ THE METAPHYSICS OF ROWAN WILLIAMS ${ }^{1}$ \\ C. J. C. Pickstock
}

The splendid word 'incarnadine', for example - who can use it without remembering also 'multitudinous seas'?

According to historical usage, the term 'natural theology' implied a necessary completion of natural scientific enquiries. It tended to denote a discipline which sought, in ontological terms, apodictically to establish God as the supreme item in a chain of items. ${ }^{3}$ In epistemological terms, it effectively presented God as but another objective item within reality which will passively endure our active search to isolate its nature.

When, in his profound reflection on languages in The Edge of Words, based on his 2013 Gifford lectures, Rowan Williams describes the work as offering 'natural theology in a new key', this self-description would seem to be given more in deference to the Gifford Bequest then to denote any continuity with the natural theological tradition as just described, whose assumptions today seem questionable, and which Williams both

1 I am profoundly grateful to Fraser MacBride for turning his critical eye upon several passages of the present essay.

2 Virginia Woolf, 'Craftsmanship', The Death of the Moth and Other Essays (Orlando, Florida: Harcourt Brace and Company, 1942), pp. 198-207, p. 201.

${ }^{3}$ Michael Buckley SJ, At the Origins of Modern Atheism (New Haven: Yale University Press, 1990). 
articulates and refuses. ${ }^{4}$ What we require today is something more like a metaphysics, which, as with the metaphysical dimension of Aquinas's thought, seeks to describe the fundamental structures of finite reality, and to gesture, with considerable reserve, towards the conditioning ground of these structures, or to "that which everyone gives the name God". ${ }^{5}$ Yet this is what Williams is here offering. In the following essay, I will seek both to describe and tentatively to develop his endeavours.

To suggest that The Edge of Words wields such a natural theological compass might seem strange, in view both of its predominant concern with human speaking, and especially poetical speaking, and its non-technical, approximate and allusive character. However, this is not a book about God-talk, nor about the internal workings of language; rather and here Williams notes the influence of John Milbank - it offers an ontological account of the place of language in reality, and subsequently the place of speaking about God within that real linguistic place of origination. ${ }^{6}$ Williams argues that one cannot give such an account without considering the nature of finite reality itself. He offers the reader a theory of the nature of reality as itself linguistic. In keeping with his insistence upon the prone and unfinished character of language, he can only, if he is to sustain logical consistency, describe this theory by performing it. This performance is a part of his proof. Sidestepping any scheme of a priori rational order or empirical generalisation, and with a

${ }^{4}$ Rowan Williams, The Edge of Words: God and the Habits of Language (London: Bloomsbury, 2014), pp. 1-10, esp. pp. 2, 10.

${ }^{5}$ Thomas Aquinas, Summa Theologiae, Ia Q. 2 a. 3

${ }^{6}$ The Edge of Words, pp. vii, 122-123. 
Coleridgean bias towards the partial truth of any human perspective, Williams populates his discourse by invoking bystanders, exemplars and witnesses. This is of a piece with the 'other rigour' of a theory of language which holds that uttered truth cannot be detached from embodied positions within both space and time, in all their non-predictability of occurrence and elective and as well as chance entailments.

At the same time, metaphysics would be too narrow a carapace in which to confine Williams's discourse. As he indicates, he is offering an ontological grammar shared by both natural and revealed theology. The received modern conception of natural theology as filling an ontic gap, ${ }^{7}$ rather than as struggling for ontological grounds of possibility for ontic givenness, is often seen as complemented by an approach to revelation whereby it is thought to be inserting one further ontic item into the world, as if arraigned for our scrutiny. As Williams argues, such an account of dogmatic theology as having a welldefined object reduces God to something inert upon which one can gaze, rather akin to the typical natural theological approach. ${ }^{8}$

In either case, Williams suggests, what is missing is history. If we attend to revelation as mediated by historical events which are only comprehensible through their antecedents and consequents, we will be disinclined to reduce the saturated character of the revealed disclosure to the ontic terms of its disclosing, though these may yet be appreciated in their ${ }^{7}$ The Edge of Words, p. 180.

${ }^{8}$ The Edge of Words, p. 5. 
fathomless diversity, in contrast to a doctrinal approach which reduces theophany to a discrete or semelfactive item. Nor, Williams argues, should natural theology overlook the fact that we can only obtain a culturally and linguistically situated, and so temporallyinflected access to both natural and divine reality. This might seem like a postmodern exacerbation of modern, critical epistemology in terms of a more relativistic confinement. But, rather, Williams proffers a distinctively twenty-first century, metaphysically robust and - one might say - speculatively realist emphasis. ${ }^{9}$ For his argument is not that historical mediation provides a sceptical barrier to the knowledge of nature, and of essences, but rather that nature herself, especially for a post-evolutionary perspective, may be seen as inherently historical, and, in this respect, as proto-linguistic. Here the work of Conor Cunningham is cited. ${ }^{10}$ For Williams, matter begins to matter, and, indeed, he argues that matter is better understood through language, than language through matter. ${ }^{11}$ Intelligent, speaking life is not plausibly regarded as an accidental upshot or by-product of evolution, but rather, the linguistic sphere is seen to complete and render clearer natural existence, and is by no means an insensate instrumental mirror which passively reveals its true character.

9 See Tom Sparrow, The End of Phenomenology: Metaphysics and the New Realism (Edinbrgh: Edinburgh UP, 2014);Peter Grafton and M. W. Austen, Speculative Realism: Problems and Prospects (London: Continuum, 2014); Graham Harman, Towards Speculative Realism: Essays and Lectures (New York: Zero Books, 2010).

${ }^{10}$ The Edge of Words, pp. 101-2, p. 106.

${ }^{11}$ The Edge of Words, pp. 35-65, pp. 95-125. 
By adopting a kind of evolutionary idealism, ${ }^{12}$ Williams aligns his project with the ideal realism of much mediaeval scholasticism, and especially that of Thomas Aquinas, for whom, after Aristotle and Augustine, materialised form is continued in another and higher - if, for embodied creatures, a less substantive - mode, as the form and word of thought. ${ }^{13}$ For Aquinas, the truth of speaking does not concern pre-mental realities. It is rather that the latter carry a freight of structure, meaning and truth which are better though abstractly and provisionally - realised in spoken thought. For this perspective, as Williams signals, truth is as much an event as a declaration. According to his terminology, one can combine both senses by speaking of "re-presentation". By this term, Williams distances himself from Wittgenstein's notion of truth as picturing, or representation, as put forward in the Tractatus. ${ }^{14}$ To reveal in an exact way is to repeat differently, and paradoxically to enlarge upon, add to or dilate that of which one speaks, in such a manner that one's addition becomes an ineliminable - perhaps even an exalted - if most abstracted part of that which is disclosed. The dilation proffered by speakers is a meaningful floreation or "nourishment" which serves as a kind of gift, as Williams suggests. ${ }^{15}$ And it is at this point that meaningful abstraction is re-embodied in the linguistic community, in such a way that human beings are shown to be the disclosing culmination of the natural order.

\footnotetext{
${ }^{12}$ One could situate this within the Anglican liberal Catholic tradition; see Charles Gore ed, Lux Mundi: A Series of Studies in the Religion of the Incarnation [1891] (London: Forgotten Books, 2012).

${ }^{13}$ See the second section of Olivier Boulnois, Métaphysiques rebelles : Genèse et structures d'une science au Moyen Age (Paris: P. U. F., 2013), "Les deux sens de la transcendence selon saint Thomas d'Aquin".

${ }^{14}$ Ludwig Wittgenstein, Tractatus Logico-Philosophicus (London: Routledge and Kegan Paul, 1961), 1.1.

${ }^{15}$ The Edge of Words, p. 33.
} 
However, as Williams describes, in terms which bring Wittgenstein and Merleau-Ponty together, there is no anterior moment of isolated nomination. Nature is linguistic, articulating herself to us in several ways; and human speech continues as corporeal interarticulation, in such a way that the psychic, which rides upon or is wrapped around the bodily vehicle, is a constitutively inter-psychic sphere. Signs arise as always already agreed upon, symbolically exchanged by speaking bodies who perform and inflect them with a certain consensus, and yet always in diverse fashion, since such bringing-together is experienced as analogical sharing, and not projective or instinctual empathy. ${ }^{16}$

By adopting this framework, Williams faithfully elaborates the Thomistic sense of truth as added event in order to accommodate a modern awareness of the unavoidability of embodiment, gesture, language and figured inflection. Here one senses a movement away from twentieth century philosophy, and a renegotiated emphasis in Williams's own reflections. It has been argued that much mainstream philosophy of the last century concerned what the analytic philosopher Peter Unger has described as "empty ideas", or ideas which are concretely insubstantial. ${ }^{17}$ Such an approach tends to identify the supposed inner consistencies and protocols of a postulated third realm of abstract

\footnotetext{
${ }^{16}$ The Edge, pp. 95-125. On the natural life of words, see Woolf, 'Craftsmanship': “Words [. . .] are full of echoes, of memories, of associations - naturally. They have been out and about, on people's lips, in their houses, in the streets, in the fields, for so many centuries [. . .] [T] hey are so stored with meanings, with memories, that they have contracted so many famous marriages." (p. 201).

${ }^{17}$ Peter Unger, Empty Ideas: a Critique of Analytic Philosophy (New York: Oxford University Press, 2014), p. 6. But see Timothy Williamson's review, The Times Literary Supplement, 5833 (January 16 2015), pp. 22-23.
} 
propositional entities available to human consciousness existing apart from physical realities. ${ }^{18}$ This realm could be variously the domain of logical or linguistic processes, or of intuited and intended phenomena. Either way, it was held to be irreducible to real things out there, and to consciousness or judgement in here. This perspective of critical realism, which includes both analysis and phenomenology, was apparently saved from idealism by the presumption of correlation between the third realm and an empirical surface layer of the real, a "non-sensible something" without which "everyone would remain shut up in his inner world". ${ }^{19}$ However, such correlation was not given any scientific warrant, and, by definition, it could not be justified within the terms of philosophy so defined. A certain emptiness and pointless self-reference ensues, ${ }^{20}$ to produce perspectives which do not sufficiently engage with the findings of modern science concerning the cosmos, on the objective side, and concerning the brain in terms of the objective grounds of the subjective. Some more recent philosophy has, by contrast, embraced naturalistic perspectives (in the analytic case, somewhat in the wake of W. V. O. Quine, Ruth Barcan Marcus and Donald Davidson), ${ }^{21}$ which it can be tempting for

${ }^{18}$ Gottlob Frege, 'The Thought', P. T. Geach tr Mind 65.259 (1956), pp. 289-311. See also Michael Dummett, 'Frege's Myth of the Third Realm', Frege and Other Philosophers (Oxford: Oxford University Press, 1991), especially pp. 251-2; Tyler Burge, 'Frege on Knowing the Third Realm', Mind 101 (1992), pp. 633-50.

${ }^{19}$ Frege, 'The Thought', p. 309. On correlationism, see Quentin Meillassoux, After Finitude: an Essay on the Necessity of Contingency Ray Brassier tr (London: Continuum, 2009).

${ }^{20}$ Margaret Masterman, 'Metaphysical and Ideographic Language', British Philosophy in the Mid-Century C. A. Mace ed (London: Allen and Unwin, 1957), pp. 283-357, p. 328. See also her aside, 'Fictitious sentences in Language', Essays on and in Machine Translation (Cambridge: Cambridge Linguistics Research Unit, 1959), Memorandum ML91, p. 18.

21 See W. V. O. Quine, 'The Scope and Language of Science', British Journal for the Philosophy of Science 8 (1957), pp. 1-17; Theories and Things (Cambridge, MA: Harvard University Press, 1981); Ruth Barcan 
theology to abhor, having been invested in the abovementioned neutral but empty approaches of analysis and phenomenology, which at least appeared to guard against reduction to the empirically evidential, on the one hand, or the biologically relativistic, on the other. ${ }^{22}$

However, to face up to the fullness of the real is not necessarily to invite reduction. Several recent atheist philosophers have suggested that a direct examination of the things themselves points towards realism and a certain hylomorphism, and not to naked materialism. ${ }^{23}$ Equally, neural science has at times tended to undercut initial reductive ambitions. Rather, as Williams describes, analogical and holistic mental operations appear to have demonstrable physical equivalents. ${ }^{24}$ By invoking neurology, as for Graham Ward, ${ }^{25}$ Williams arguably aligns himself with anti-anti-psychologism, whose mental correlate is that truths are, as Aquinas held, predicated of judgements, rather than of propositions. ${ }^{26}$ To emphasise that we have the thoughts we do because we have the bodies and the brains we do, can - perhaps oddly - be seen as the opposite of reductive, insofar as judgements

Marcus, 'The Anti-Naturalism of Some Language-Centred Accounts of Belief, Dialectica 49.2-4 (1995), pp. 113-30; Modalities: Philosophical Essays (Oxford: Oxford University Press, 1995); Donald Davidson, Essays on Actions and Events, Oxford: Clarendon Press, 1980), especially 'Mental Events', pp. 207-225.

${ }^{22}$ For a critique of anti-psychologism, see Martin Kusch, Psychologism: The Sociology of Philosophical Knowledge (London: Routledge, 1995).

${ }^{23}$ Tristan Garcia, Form and Object: a Treatise on Things Mark Allen Ohm and Jon Cogburn trs (Edinburgh: Edinburgh University Press, 2014).

${ }^{24}$ The Edge, 27-30, 189-190; Ian McGilchrist, The Master and his Emissary: the Divided Brain and the Making of the Western World (New Haven: Yale University Press, 2009).

${ }^{25}$ Graham Ward, Unbelievable: Why we Believe and Why we Don't (London: I. B. Tauris, 2014).

${ }^{26}$ Williams cites Wilfred Sellars' presentation of speaking as determined in the manner of all physical behaviour and as socially situated; see Science, Perception and Reality (London: Routledge and Kegan Paul, 1963) and Science and Metaphysics: Variations on Kantian Themes (London: Routledge and Kegan Paul, 1968). 
are made by conscious, or immanently conscious, flesh and blood creatures. Biological relativism is not involved here, if, as Williams argues, human speaking bodies are objectively disclosive of the real. It is because of his distancing from anti-psychologism, as well as from an hermetically-sealed third realm, that Williams claims representative truth not just for indexical statements, which might readily be digitised, but for complex symbolic truth which calls for judgement to be exercised. He seems to follow a realist phenomenology without idealist epoché, following the ontological drift of Maurice MerleauPonty, whose thought lies in the wake of the spiritual realist Maine de Biran, as well as that of Edmund Husserl. Williams seems prepared to allow that the condition of the kinds of truth to which human beings have access is inseparable from the structures of their brains, the integration of brain and body and the social rituals of their embodiment.

The "empty" assumptions of twentieth century philosophy, mentioned above, can arguably be traced to the ontology of Bernard Bolzano, which was indebted to late Iberian and Bohemian Jesuit scholasticism. This lineage has been seen as the context for the apparent, though not wholesale, ${ }^{27}$ movement from the Thomist assignment of truths to

27 The apparent re-assignment of truth from the domain of judgement to that of propositions was not universally accepted. Bertrand Russell and Ludwig Wittgenstein, for example, continued to think of judgement as the ultimate truth-bearer, and of propositions as abstractions from judgement. I am grateful to Fraser MacBride for this refinement. See Fraser MacBride, 'Truthmakers', The Stanford Encyclopedia of Philosophy (Spring 2014 Edition), Edward N. Zalta ed [http://plato.stanford.edu/archives/spr2014/entries/truthmakers/]. 
judgement, to their reassignment to propositions. ${ }^{28}$ Truth appeared no longer to have need of a truth-maker, or else the role of truth-maker had become confined to entailment or necessitation. ${ }^{29}$ The etiolated realism to which this abandonment or confinement of the truth-making role gave rise often seemed preferable, especially within Catholic thought, to a Kantian subjectivism and exclusion of theoretical knowledge of noumena. But, as we have seen, it was inadequately defended against subjectivism, and in addition, it could only break from its formal circle by recourse to speculation and invocation, rather than pure description, while this circle was itself threatened by the exceptions to non-contradiction revealed by the Russell-Zermelo paradox. ${ }^{30}$ It is notable that further shifts have occurred; Graham Priest and Richard Routley, for example, are prepared to sacrifice logic to reality, feeling no impulse to shore up logical conundrums with arbitrary ruses. ${ }^{31}$ According to Priest's dialetheism, or refusal of the ultimacy of non-contradiction, containing sets or bounds are typically contained and yet not contained in what they include, and are within

28 Jan Berg, Ontology Without Ultra-Filters and Possible Worlds: An examination of Bolzano's ontology (Bahnstr.: Academia Verlag, 1992); Jacob Schmutz, 'Réalistes, nihilistes et incompatibilistes: Le débat sur les negative truthmakers dans la scolastique jésuite espagnole’, Dire le Néant: Cahiers de philosophie de la Université de Caen Basse-Normandie No. 43 Jérôme Laurent ed (Caen: Presses Universitaires de Caen, 2007), pp. 131 178; J. Alberto Coffa, The Semantic Tradition from Kant to Carnap (Cambridge: Cambridge University Press, 1993), pp. 22-40.

${ }^{29}$ MacBride, 'Truthmakers'. It is not that truth is made, in the sense of a pot being made, but rather, "a truth-maker is that in virtue of which something is true”. J. Bigelow, The Reality of Numbers: A Physicalist's Philosophy of Mathematics (Oxford: Oxford University Press, 1988), p. 125.

${ }^{30}$ Godehard Link ed, One Hundred Years of Russell's Paradox (Berlin and New York: Walter de Gruyter, 2004).

${ }^{31}$ Graham Priest, R. Routley and J. Norman eds, Paraconsistent Logic: Essays on the Inconsistent (München: Philosophia Verlag, 1989). See Jacob Holsinger Sherman, Partakers of the Divine: Contemplation and the Practice of Philosophy (Minneapolis: Fortress Press, 2014), p. 55. 
and yet outside the limits they define. ${ }^{32}$ For this reason, logical items cannot be mustered as a phalanx against a logically anarchic reality; Priest here invokes Nicholas of Cusa, De docta ignorantia I.VI. Rather, logical items are part of a universe of variegated things which, as Aristotle thought, though without advancing to paradox, arise with the terms of 'including' and 'being included', whether in the case of rocks or flowers or grammars. ${ }^{33}$ So, realism might be genuine and speculative, rather than critical, and it might start directly with things, rather than reflexively with our knowledge of things, because the critical domain has turned out to lack foothold, rather as Wittgenstein suggested as a response to Russell's Janus-headed paradox, “Might one not even begin logic with this contradiction? And as it were descend from it to propositions?" ${ }^{34}$ The critical domain is secured neither in a posteriori evidence, nor a priori structures of reason. Rather, these always already qualify one another in such a manner that prevents the isolation of a clear startingpoint. ${ }^{35}$ Finally, as noted, the formal circle is not self-founded within non-contradiction, outside the greatest emptiness of all, which is tautology.

32 Graham Priest, Beyond the Limits of Thought (Cambridge: Cambridge University Press, 1995); on Cusanus, pp. 23-24. See also Johannes Hoff, The Analogical Turn: Rethinking Modernity with Nicholas of Cusa (Grand Rapids, Michigan: Wm. B. Eerdmans Publishing Co, 2013), pp. 29-32. The inspiration for Graham Priest's 'dialetheism' came from Ludwig Wittgenstein, Remarks on the Foundations of Mathematics (Oxford: Basil Blackwell, 1978), where he describes the Liar sentence ('This sentence is not true') as a Janus-headed figure facing both truth and falsity (IV.59).

33 Masterman, 'Metaphysical and Ideographic Language', pp. 311, 358.

34 Wittgenstein, Remarks on the Foundations of Mathematics IV.59.

35 W. V. O. Quine, 'Main Trends in Recent Philosophy: Two Dogmas of Empiricism', The Philosophical Review 60.1 (January, 1951), pp. 20-43. 
Williams's realist approach to language could be seen as fitting within this contemporary movement. Indeed, he touches upon the question of the irreducibility of paradox with respect to the thought of Margaret Masterman. ${ }^{36}$ One could suggest that within an inhabited and realised, yet comprehending boundary, one which does not obtain to an absolute compass, two perspectives might be incompatible, yet both required, while without that boundary, which is infinite with respect to that boundary, they can be seen as fused. ${ }^{37}$ It seems that Williams does not wish to have recourse to Kant in the face of the collapse of the Bolzanian project. As he says, Kant was rightly dismantling the false perspectives of a later scholasticism which tended to argue to God as an ultimate item in continuity with other items. ${ }^{38}$ But Kant did not envisage that there might be non-ontic and non-graspable conditions of the possibility of the real, and not just of thought. It is clear that Williams does not think that such an exclusively epistemological endeavour is viable. This is because our thinking is not immunised against unpredictable physical and cultural influences, which can disturb our sense of what might be fundamental and transcendental. Nevertheless, he notes that the critical rigour of Kant's demolition of a decadent scholastic does not leave Thomism unaffected, even if it leaves it mostly in place. This is because it has since purged itself of elements within Aquinas's thought which

\footnotetext{
${ }^{36}$ Masterman, 'Metaphysical and Ideographic Language'.

37 The Edge, 126-127; Masterman, 'Metaphysical and Ideographic Language'; see especially "Postscript", pp. 357-8. See also Margaret Masterman, 'Translation', Aristotelian Society Supplementary XXV (1961), pp. $169-216$.

${ }^{38}$ Immanuel Kant, Critique of Pure Reason Norman Kemp Smith tr $\left[2^{\text {nd }}\right.$ impression] (London: Macmillan, 1933), 507-14. The Edge, pp. 11-18.
} 
appeared to confuse the ontological with the ontic, and so has reinforced the ideal side of its ideal realism with a greater attention to cultural mediation and addition. ${ }^{39}$

In the foregoing, I have indicated ways in which one can situate The Edge of Words within what one might describe as a post-postmodern context; one which seems to have moved away from the dogmatism of agnostic seclusion, and the sceptical reaction against it in favour of naturalistic realism.

However, at the core of Williams's natural theology, one finds a new kind of argument for God. This is not just for the God of Creation, but for a more specifically Christian deity. For Williams, history mediates between the witness of nature and that of revelation, and so his argument concerns a cultural grammar of analogy or naming God, and a natural longing for union with the divine perspective which is, for Christian tradition, by free divine gift. ${ }^{40}$ One could suggest that Williams is exploring, after Erich Przywara whom he cites, a realm between philosophical theology and sacred doctrine which is crucial for both; it is not a propaedeutic practice, but rather a continued necessity for their intellectual unity. ${ }^{41}$

\footnotetext{
39 The Edge, pp. 11-14.

${ }^{40}$ John Milbank, The Suspended Middle: Henri de Lubac and the Debate Concerning the Supernatural (Grand Rapids, Mich.: Eerdmans, 2014).

${ }^{41}$ The Edge, p. 20; Erich Przywara, Analogia Entis: Metaphysics: Original Structure and Universal Rhythm Jon Betz and David Bentley Hart trs (Grand Rapids, MI: Wm. B. Eerdmans, 2013).
} 
Williams's argument, which, as we have seen, builds from ontology to theology, is that language must be added to nature, expressed in a dilation or further excess of nature, in order to represent it. Accordingly, there is no secure circle of mirroring through which the truth of language could be referred to natural reality. However, it stretches credulity to suppose that the dilation afforded by language, and so by culture and history, is merely arbitrary. Such a position would require that reality be a-rational, in such a way that thinking and speech were epiphenomenal, or included within reality under an extrinsic recourse to monistic process. If the linguistic addition to reality is indeed an addition, and yet not arbitrary, then nature must be teleologically attuned to intelligence which points to its being shaped by the intellectual as both a transcendental and a transcendent power.

To establish this argument, which is Williams's task throughout the book, he needs to show (1) that nature is not alien to language; (2) that language is not alien to nature, and (3) that the intelligent force at work in nature is more than immanent.

In order to establish (1) that nature is not alien to language, Williams observes that the structures of nature appear to be ordered by numerical pattern at a basic level, fanning out to ever more complex patterns to indicate codes at a biological level. Nature, in a nearliteral sense, communicates with herself and with us, and offers something to us the more she approaches personality. So we are encouraged, as Williams explains, following Wittgenstein, Edmund Husserl and Martin Heidegger, to interpret or read reality, as when 
discerning significance when hearing a wood pigeon cooing or when reading the expression on a dog's face. It is in the same way that we interpret texts and read words, rather than infer to a state of affairs by assembling isolated units of evidence. ${ }^{42}$ Whilst there is an instrumental explanation for this tendency, in that processes of detached inference would take too long for animal survival, one might note that its possibility depends upon the fact that nature seems to announce herself with a sort of meaningful immediacy, as expressed by E. E. Cummings in La Guerre V:

O sweet spontaneous

earth how often have

the

doting

fingers of

prurient philosophers pinched

and

poked

thee

, has the naughty thumb

of science prodded

thy

beauty, how

often have religions taken

thee upon their scraggy knees

squeezing and

buffeting thee that thou mightest conceive

gods

(but

42 The Edge, pp. 111, 115. 
true

to the incomparable

couch of death thy

rhythmic

lover

thou answerest

them only with

spring) $)^{43}$

It seems as though, for post-epistemological philosophy, if it is the case that meaning is not out there, then it could not obtain in here. ${ }^{44}$ Human speech, with its still greater variety and creativity, is not an interloper upon the domain of nature, and so, as Williams argues, we are mistaken if we complain that science has disenchanted the world. ${ }^{45}$

This conclusion seems to be in keeping with the fact that observation, experiment and speculation, which constitute scientific cognitive practice, are neutral with respect to any possibly reductive perspective, even though some might contend that such a perspective perforce grasps the world under the aspect of identical repeatability as determinative of

43 E. E. Cummings, 'La Guerre' V, Complete Poems 1904-1962 George J. Firmage ed (London: W. W. Norton, 1973), pp. 53-58, 58.

${ }^{44}$ Garcia, Form and Object, pp. 120-125.

${ }^{45}$ The Edge, p. 120. 
experimental success. ${ }^{46}$ Indeed, the objective witness of experiment has been known to indicate unaccountable forces and indicative codes irreducible to mechanism, as well as, by negative evidence, the presence of the irregular or spontaneous. One could argue that at times scientific procedure may have fallen short of the expectations of those seeking to demonstrate the transparency and predictable manipulability of the natural realm. Nonetheless, it is perhaps to this degree that science has been able to re-enchant our reality, as is the case with much modern physics. ${ }^{47}$ Equally, those who might complain of disenchantment are not perhaps targeting science, as rather those seeking to rescue reality from a reduction to what can be predicted and described. In this sense, Williams is a reenchanter in the face of a technological and spectacular drift for which scientists are not to blame. This is by no means to gainsay that there may be scientists who adhere to a technologising attitude, as if the Strong Cartesian Programme of flattening reality to an indistinct and arbitrarily divisible chronotope were still a driving force. It is perhaps imponderable if or how far such an attitude dictates the priorities of science, or determines its dependence upon technological exigency aimed at increasing formal power, size or speed. For such a perspective, though, Williams's project is, as he indeed presents it, distinctively counter-cultural.

${ }^{46}$ David Bohm, 'On the Problem of Truth and Understanding in Science', Critical Approaches to Science and Philosophy, Mario Bunge ed (New Brunswick, NJ: Transaction Publishers, 1999), chapter 14, especially p. 212. See Stephen Shapin and Simon Schaeffer, Leviathan and the Air-Pump: Hobbes, Boyle and the Experimental Life (Princeton NJ: Princeton University Press, 1985/2011).

47 See Jane Bennett, The Enchantment of Modern Life (Princeton NJ: Princeton University Press, 2001); Xin Wei Sha, Poiesis and Enchantment in Topological Matter (Cambridge, MA: MIT Press, 2013). 
In order to establish (2), that language is not foreign to nature, Williams adopts several strategies which occupy much of the book. Most of our speech, he argues, is neither directly pictorial nor descriptive. In order to describe, we must have recourse to invocation. This anterior figural process is never completed, and is matched prospectively by an accompanying sense that more has yet to be said - a sense that, for all Spring's repleteness in Cummings' poem, the gift of reality to us must be met by a counter-gift. It is as if a seascape naturally precipitates or demands an encomium, as naturally as it is shaped by swell and wave breaking. These poetic aspects of truth-making, it seems, covertly enter into our ordinary prosaic practices, and yet we are not attended by the sense that we are arbitrarily making things up or being dishonest as to the way things are. ${ }^{48}$ Do we rather feel that we are responding to the impress of reality, its imperatives ${ }^{49}$ The trope here deployed by Williams is one of completion, yet of a constitutively incomplete completion which may involve much tearing down and re-building. Above all, completion demands fiction; this is intended in the twofold sense of (a) something which can be made up or composed, and (b) a falsity which is an untruth to things, and not just a misrepresentation.

\footnotetext{
${ }^{48}$ See Woolf, 'Craftsmanship'; Masterman, 'Metaphysical and Ideographic Language', pp. 301, 307.

${ }^{49}$ See G. W. Goethe, Botanical Writings Bertha Muella tr (Woodbridge, CT: Ox Bow, 1952); Agnes Arber, The Natural Philosophy of Plant Form (Cambridge: Cambridge University Press, 1950), pp. 70-92; The Manifold and the One (London: John Murray, 1957); Pierre Hadot, Le Voile d'Isis: Essai sur l'histoire d'idée de nature (Paris: Gallimard, 2004), pp. 321-328.
} 
In the context of this discussion of the figural and asymptoptic thrall of the representation of reality in language, and the role in this of superfluity and fiction, ${ }^{50}$ Williams offers a critique of Paul Griffiths' insistence that one must tell the literal truth if one is not to betray the destiny of language as the vehicle of truth - which he is nonetheless right, as Williams notes, to emphasise. ${ }^{51}$ Ibsen's The Wild Duck is invoked to re-articulate the difficulty. ${ }^{52}$

Words, then, are not merely to be seen as proffered analogies as to content; they are themselves analogous, as words to things. Williams resists the arbitrariness of the sign, and, through an invocation of Aristotle's model of the action of an object's form upon the knowing subject, indicates that he is aware how close this brings him to a magical theory of speech. ${ }^{53} \mathrm{He}$ is careful, though, to distance himself from a reduced magic of one-toone wonder-working correspondence of word or process to thing. However, if, as ethnographers such as Marcel Mauss have argued, magic is an irregular ritual art summoning a learned prudence, ${ }^{54}$ then the account of poetry given by Williams, for which words invoke, conjure and fulfil, would seem magical to the degree that a kind of occult affinity were at stake. I suggest the word 'occult' because one cannot survey such a likeness without recourse to poetry, so rendering it irreducible to description; and

\footnotetext{
50 Masterman, 'Metaphysical and Ideographical Language', pp. 335-6.

${ }^{51}$ Paul Griffiths, Lying: An Augustinian Theology of Duplicity (Grand Rapids, MI: Brazos Press, 2004).

52 The Edge, pp. 46-50.

53 The Edge, pp. 109-110.

${ }^{54}$ Marcel Mauss, A General Theory of Magic Robert Brain tr (London: Routledge, 2001).
} 
'affinity', because we would otherwise be wrong to exercise faith that words can represent; this is the faith which Williams calls for throughout this book. Aleksei Losev and Sergei Bulgakov, the Russian symbolist philosophers whom he invokes, consciously sought to bring together the esoteric with mainline theological tradition. ${ }^{55}$

Williams elaborates his theory of poetic representation with a beautiful account of Welsh poetry. ${ }^{56}$ The mark of the enchantment of traditional poetry, of which Welsh prosody is a refined example, is seen in the way in which strict and complex rules concerning rhyme, assonance, alliteration and other sound patterns encourage the discovery of unexpected affinities between word, meaning and evoked reality. As Williams says, such resonances, though wrought by a tightly disciplined art, cannot be ruled in advance, and there may be surprises in the realisations which we receive. ${ }^{57}$ One might suggest that the modernist reaction against the formal use of such traditional means, whilst it could indicate a disenchanting warrant to anarchy, the aleatory or psychological expressionism, might be seen as a reaction against a perceived weariness of enchantment, for which associations have become predictable, patterns lacking in surprise or personifications of nature worn by familiarity. From such a perspective, modernism had to re-enchant our perception by

\footnotetext{
${ }^{55}$ The Edge, pp. 110-1; see further John Hughes, 'Bulgakov's move from a Marxist to a Sophist Science', Sobernost 24.2 (2002), pp. 29-47.

56 The Edge, pp. 132-134. See Masterman's discussion of Chinese poetry, 'Metaphysical and Ideographic Language', p. $349 \mathrm{ff}$.

57 For a similar non-Saussurean analysis of the accumulated and non-arbitrary layers of affiliation in the sound-attachments of traditional verse forms, see J. H. Prynne, Stars, Tigers and the Shape of Words (London: Birkbeck, 1993); see also Woolf, 'Craftsmanship’.
} 
approaching things the other way around, by searching for the word or pattern which would fulfil a certain reality, or an idea not fully present until the right word or pattern could be found. As for Ezra Pound and T. S. Eliot, such modernism does not pretend to the aleatory, but rather to free play or spontaneity within established formal games. By the same token, nature could speak again if her voice issued, as it were, directly and without stale familiarity, from her: "April is the cruellest month, breeding | Lilacs out of the dead land". 58

Williams's metaphysics retains a modernist as well as symbolist nature. He seems welcoming of formal philosophic and poetic devices, yet with an eye to spontaneity, so as to realise the formal affinities which are needed in order to show unexpected affinities.

Two comments follow here. First, one might suggest that such an approach, which lets content lead to form, as well as form to conjure content, is very magical indeed. And, secondly, a link might be drawn between (a) the poetic balance of discipline and spontaneity, being linked with its potential for an addition, or "discovery", and not mere representation, and (b) Masterman's ideographical interlingua. Masterman's optimism concerning the creative potential of the computer and the contrivance of machine translation are easy to set aside in the light of our dominant sense of the computer as "a

58 T. S. Eliot, 'The Waste Land', Poems 1909-1925, I, lines 1-2, (London: Faber and Faber, 1932), pp. 81 109, p. 83. See also 'Gerontion': “In the juvescence of the year | Came Christ the tiger | In depraved May, dogwood and chestnut, flowering judas, | To be eaten, to be divided, to be drunk | Among whispers", Poems pp. 49-53, lines 19-23. 
myriad of clerks or assistants in one convenient console". ${ }^{59}$ This passive or representational construal of the computer is not due to a limit or deficiency in its technological compass, but rather to our own confined use of the computer as a receptacle, and our replicating of a minimal notion of writing as a useful device to retain discrete facts, as suggested by the Egyptian God Thamus, in Plato's account of the myth of the invention of writing in Phaedrus. ${ }^{60}$ For this interchange between Theuth and Thamus, writing is in no way connected with the generation of true knowledge, but rather seen as a passive facility for reminding. ${ }^{61}$ One notes a parity between this and our quantitative notion of measurement as a neutral tool which leaves the world as it is. ${ }^{62}$ By contrast, for Masterman and others, her techniques were thought to defamiliarise our perception, forcing "a crisis of understanding from which a new, more adequate cosmology arises". ${ }^{63}$

59 Susan Wittig, 'The Computer and the Concept of Text', Computers and the Humanities 11 (1978), pp. 211 215.

60 "The story goes that Thamus said many things to Theuth in praise or blame of the various arts, which it would take too long to repeat; but when they came to the letters, 'This invention, O king', said Theuth, 'will make the Egyptians wiser and will improve their memories; for it is an elixir of memory and wisdom that I have discovered'. But Thamus replied, 'Most ingenious Theuth, one man has the ability to beget arts, but the ability to judge of their usefulness or harmfulness to their users belongs to another; and now you, who are the father of letters, have been led by your affection to ascribe to them a power the opposite of that which they really possess. For this invention will produce forgetfulness in the minds of those who learn to use it, because they will not practice their memory. Their trust in writing, produced by external characters which are no part of themselves, will discourage the use of their own memory within them. You have invented an elixir not of memory, but of reminding; and you offer your pupils the appearance of wisdom, not true wisdom, for they will read many things without instruction and will therefore seem to know many things, when they are for the most part ignorant and hard to get along with, since they are not wise, but only appear wise'”, Plato, Phaedrus H. N. Fowler tr (Cambridge, Mass.: Harvard University Press, 1925), 275a-b.

${ }^{61}$ Phaedrus, 277d.

62 Willard McCarty, 'A telescope of the Mind?' Debates in Digital Humanities Matthew K. Gold ed (Minneapolis MN: University of Minnesota Press, 2012), pp. 113-123, p. 113-4. McCarty cites Thomas Kuhn, 'The Function of Measurement in Modern Physical Science', Isis 52.2 (1961), pp. 161-93.

${ }^{63}$ McCarty, 'A Telescope for the Mind?' p. 113. 
Along similar lines, Herbert Simon, for example, wrote, "Machines think! Learn! Create!" One thinks of the alternative, higher writing on the soul, described by Socrates as "written with intelligence in the mind of the learner", ${ }^{4}{ }^{4}$ and one wonders how one might nowadays reconstrue theologically the relationship between writing and philosophy in the light of the foregoing discussions, and especially the advance in the digital economy with its own innate patterning, relational vertices and peculiarly panoptic scope for yoking disparities.

It is less clear, perhaps, how Williams is to establish (3), that the divine intellectual force is not merely immanent. He seems to problematise this task by rightly denying a closed account of the self-sufficiency of finite substance, for if substances are ultimate, they tend to depend upon an ultimately vertical explanation, as for Aristotle. Following Margaret Masterman, he sidelines the linguistically concomitant expression of things in terms of subject and predicate, ${ }^{65}$ in favour of an ideogrammatic approach to an holistic picture, "fan" or "spray" of a thing, ${ }^{66}$ through its complex co-ordinates, near and far, causal, simultaneous and consequent, via a kind of panoptic mapping or archiving of contingency. ${ }^{67}$ Such an approach, philosophically adjacent to A. N. Whitehead's fractal

\footnotetext{
${ }^{64}$ Phaedrus, 276a.

${ }^{65}$ Masterman, 'Metaphysical and Ideographic Language', p. 309; pp. 318, 330.

${ }^{66}$ On semantic message detection for machine translation using an interlingua, see Masterman, Language, Cohesion and Form (Cambridge: Cambridge University Press, 2005), pp. 83-106; on the "fan" or "spray", see pp. 39-56. See also Masterman, 'Metaphysical and Ideographic Language', p. 357.

${ }^{67}$ The Edge, pp. 105-108. This approach, and the role of new technology, were seen to have far-reaching socio-political and cultural implications, especially in the context of the European Commission; see
} 
metaphysics, can seem to favour the ultimacy of event and process. ${ }^{68}$ One notes, however, a resonance with Tristan Garcia's recent speculative realist work, Form and Object, in which he abhors the supposed "compactness" of ultimate and self-enclosed process, as well as the compactness of pure substance as inclined to deny the irreducibility of the singular thing. ${ }^{69}$ For although he might not subscribe to Garcia's ontological latitude and refusal of hierarchical and relational embedding, ${ }^{70}$ it is apparent that Williams shares a distancing from compactness of process. He is clear in his resistance to immanent comprehensiveness, whether material or intellectual, and the reduction of relationality to the necessary internal constitution of a thing, though relations are not to be exhausted by accidental externality. ${ }^{71}$ Rather, ideographical clusters or vertices of interlocking networks, densities and pressures obtain at all intermediate levels of reality, but there is no authoritative or natural calligraphy. ${ }^{72}$ It is this middle position which we must try to echo in our own writing, if its many-sidedness is to give us to, and embed us within manysided reality. ${ }^{73}$

Masterman, “The Essential Skills to be acquired for Machine Translation”, Translating and the Computer B. M. Snell ed (Amsterdam: Elsevier Science Ltd, 1979), pp. 159-180, p. 159. Other examples of the application of the ideographic interlingua are explored, for example, by Margaret Masterman, R. M. Needham and K. Spärck Jones, 'The Analogy between Mechanical Translation and Library Retrieval', Proceedings of the International Conference on Scientific Information (Washington DC: National Academy of Sciences, 1958), pp. 917-935. For a discussion of the way in which the potential of machine translation, as envisaged by Margaret Masterman and others, has not been realised, see McCarty, 'A telescope of the Mind?’ pp. 113-123, and see main text above.

${ }^{68}$ Masterman, 'Metaphysical and Ideographic Language', p. 311 ; see also The Edge, p. 105.

${ }^{69}$ Garcia, Form and Object, pp. 19-74.

${ }^{70}$ The Edge, p. 99.

${ }^{71}$ The Edge of Words, pp. 107-108.

${ }^{72}$ Masterman, 'Metaphysical and Ideographic Language', p. 310.

${ }^{73}$ On many-sidedness, see Woolf, 'Craftsmanship'. 
This implies interplay between the relational and the lapidary or substantive. ${ }^{74}$ Substance cannot be dissolved, any more than it can be rescued by Williams in the manner of Garcia, via an ontologistic monadology for which every thing - reality, sign, idea - enjoys transcendental priority and disconnection from the lattices of inclusion which characterise a thing's phenomenal existence. ${ }^{75}$ For such a transcendental democracy, each thing is identical with the void from which it is subtracted. Williams, by contrast, considers there to be what one might call meta-relations between the knots and clusters which are substantive things, and the networks of relations from which they are inseparable. To embrace such a reality, though it conforms to common sense, implies a hidden holdingtogether, both in terms of the regular habits which constitute things, and the regular habits which connect things together. One might invoke a further theme in Masterman's writings, namely, the idea that, for both nature and language, the same thing is always being said and done, but with myriad tiny variations. ${ }^{76}$ There is no sameness without these variations, as was affirmed by Søren Kierkegaard, Félix Ravaisson and Charles Péguy. ${ }^{77}$ One might indeed connect Williams's argument to God, which, according to the subtitle of his book, is concerned with the habits of language, with Maine de Biran and Ravaisson's distinction between the valued and good habits of non-identical repetition and

\footnotetext{
${ }^{74}$ Masterman, 'Metaphysical and Ideographic Language', pp. 294, 309.

${ }^{75}$ Garcia, Form and Object, pp. 19-80.

76 Masterman, 'Metaphysical and Ideographic Language', pp. 309-315.

${ }^{77}$ For elaborations on this point, see Catherine Pickstock, Repetition and Identity (Oxford: Oxford University Press, 2013), pp. 28-39; pp. 99-101.
} 
bad habits of identical repetition mixed with randomness. For this distinction, if good habits are considered to be natural, then they indicate the workings of intelligence, and even grace - as gift and beauty - within nature, since nothing immanent can precede a habit if it is fundamental. ${ }^{78}$ Williams's perspective implies that neither substance nor process is irreducibly basic; rather, the habitual interplay between lapidary identity, itself habituated, and the typical relations and co-ordinates in which it stands, are basic. If these are to be transcendentally accounted for, and not reduced to surd meaningless persistence or randomness, these partially intelligible fluid structures perforce derive from a transcendent intellectual plenitude. Williams links this perspective with his own more open-windowed version of monadology, inspired by David Bohm's notion of implicate order: each finite reality gestures in its microcosmic structures and signs to a presupposed completed whole, which however can never be present within time. ${ }^{79}$

The interplay between substance and process is therefore necessarily also one between things and transcendent universals, since it is the surplus of universality (and ultimately of divine ideas) which forbids any compact closure, whether by the discrete thing or by the finite flow of reality. In Masterman’s terms, which Williams echoes, this vertical tension

\footnotetext{
${ }^{78}$ Félix Ravaisson, Of Habit Clare Carlisle and Mark Sinclair trs (London: Continuum, 2008). See further the (as yet unpublished) doctoral dissertation of Simone Kotva, 'Repetition and Reciprocity: Philosophies of Suffering in the Stoicisms of Gilles Deleuze and Simone Weil' (Cambridge University, 15 April 2015), chapter 2.

79 The Edge, pp. 104-108, referring to David Bohm, Wholeness and the Implicate Order (London: Routledge and Kegan Paul, 1981).
} 
is, however, played out at an horizontal level. ${ }^{80}$ One finds a tension between substance and process, or between relatively stable subjects and predicated events, in keeping with subject/predicate grammar, but also a tension between relatively general initial indications of a thing or states-of-affairs and a relatively particular modifying, superadded, statement, according to grammatical ideography, as when one adds 'greenness' to 'treeness', rather than 'green' to 'tree'. For this approach, ordinary language is always computationally reckoning with the metaphysical, since universal, metaphysical notions are part of its very composition. And, as Masterman argues, since the initial concept is somewhat open to vagueness, the qualifying term can be perceived as analogically akin to it, without one being able to reduce this likeness to univocity. In an equivalent way, it can also be unlike, without one being able to reduce this to equivocity. The reason for this likeness and unlikeness, in both cases, is that the initial statement is not sufficiently precise for one to secure exactness of agreement or contradiction. Rather, the addition of ideographic qualifications is itself the very attempt to arrive at further exact specification or disambiguation, even though this process can never be brought to completion, but involves receding aspectual insight. Masterman here echoes Husserl and Heidegger as well as Wittgenstein.

In this way, Masterman suggests, paradox is never outright, or at its uttermost point, since that would depend upon an initial univocity of terms which is not available. Rather, the

\footnotetext{
${ }^{80}$ For the following discussion, Masterman, 'Metaphysical and Ideographic Language'.
} 
practicable exigent site or instantiation of paradox (and here one detects a kinship with Kierkegaard) is that of non-identical repetition. What Masterman offers is a palliation of paradox which falls short of outright deflation. And this is closely connected with a nonor post-nominalist interplay between unavoidable abstract or universal terms, on the one hand, and relatively - for this contrast can only be one of degree for the ideographic perspective - more concrete ones, on the other hand. Repetition (of the kind of which Kierkegaard, Charles Péguy and Gabriel Tarde spoke $)^{81}$ is defined by non-identical variation because the universal is never sufficiently determinate as universal, and likewise, the particular never attains to sufficient determination as particular. And so it is the case that these two levels constantly interfere with one another in human discourse and have always already done so.

For realist scholastic thought, in the finite world, a universal is only realised in a thing or a thought (which is also a kind of res), while inversely, a thing only exists as expressing a universal. One finds here a kind of paradoxical coincidence, which the nominalists often construed as unacceptably contradictory. ${ }^{82}$ Masterman, however, suggests a means by which one might relatively deflate such an appearance of contradiction, insofar as the particular thing is not outright and so problematically identical, as particular, with its opposite, which is a universal, since its particularity is salvaged through an asymptotically

\footnotetext{
${ }^{81}$ Pickstock, Repetition and Identity, pp. 21-40.

${ }^{82}$ See, for example, William Of Ockham, Summa Logicae I. 15, 5-6; Ordinatio I d. 2 qq. 4-8; Quodlibet II 4 resp; IV 9; VI 25; XIII a.1; Reportatio III q. 9. See also Kurt Flasch, Philosophie mediévale Jeanne de Bourgknecht tr (Paris: Flammarion, 1987), p. 106.
} 
aspectual differential iteration. Equally, universality is recouped by virtue of its transcendent surplus to this process, which never completely expresses what there is to be expressed.

Masterman notes that this interplay applies to God, in the case of the Christian doctrine of the Trinity. For this doctrine, it is not simply that God is one and three in different contexts according to propositional logic; one, for example, when we are speaking of the Godhead's creative action, and three, when we are speaking of incarnation and the descent of the Spirit. ${ }^{83}$ But, in addition, it pertains that the divine Unity in itself can only be adequately explicated as three, according to an ideographic logic for which "we have a feeling of absorbing parallel clusters, rather than of making statements, from first to last". 84

However, it remains the case, as Masterman does not say, that paradox is not hereby exhaustively qualified. This is because these many non-identical repetitions are held to coincide with the ineffable unity of the universal, including the Trinitarian personal iteration of the divine essence, which Nicholas of Cusa described as 'repetition' ${ }^{85}$ And this perfect coincidence is also exemplified by the circumstance that the universality of the universal is not guaranteed only by its reserve, but also by its own repetition through new particular invocations. In the case of the Trinity, however, the reserve absolutely and

\footnotetext{
83 'Metaphysical and Ideographic Language', 306.

84 'Metaphysical and Ideographic Language', p. 346.

${ }^{85}$ Pickstock, Repetition and Identity, pp. 193-197.
} 
unthinkably coincides with the repeated expression. To recall, it is just this repeatability of the universal (and not just that of the particular) which defines and allows nonidentical repetition. For this reason, the scenario described at the end of the last paragraph is reversible. It is equally true to say that the surplus of universality is recouped through the need for non-identical repetition, and that this repetition is never equal to the transcendent singularity of the ineffable particular. Non-identical repetition does not serve to distinguish the way in which something is universal from the way in which it is particular, and so to deflate paradox. Rather, it reasserts a coincidence of the two to the point of apparent contradiction. One can only palliate this contradiction by playing through or inhabiting the never-ending tension of such coincidence in iterative, analogical variation. This is perhaps best accommodated or captured by an ideographic grammar. But it is only in God - in whom the particular and universal, original and image, infinitely coincide - that this tension is both fulfilled and overcome. In the finite world, we must be reconciled to the perplexity of the interplay of the particular and universal which is the reflex of the incomprehensible grounding of the finite in the infinite. ${ }^{86}$

Williams appears to affirm the irreducibility of metaphor and analogy in their paradoxical extremities which involves an horizontal and irresolvable exchange between universal and

86 See Johannes Hoff's response to Daniel O'Connell, 'Cusa, Modernity and the "other" Dominican tradition' in the symposium on Hoff, The Analogical Turn: Rethinking Modernity with Nicholas of Cusa, in Syndicate: A New Forum for Theology (forthcoming in May/June 2015) 
particular in accord with a balancing of substance and process upheld by a participation in transcendence.

Immanence could nevertheless be said to operate as a kind of foil in The Edge of Language, a foil or counterpoint which is partially entertained. One can observe parity between Williams's deployment of the Zen koan, his rendering of negative theology, his invocation of Hegel and his theme of language as incomplete. In discussing these four examples, Williams persuasively shows that one cannot assert the completion of a finished or caused thing, work or expression, but, at the same time, one should not exalt absence, negation, failure or exhaustion. Against sentimental invocations of silence, Williams advises of the necessity of situation to any significant pause or ellipsis. It is articulated along with affirmations, and indeed there can be no affirmations not so punctuated. ${ }^{87}$ However, might one suggest that the Zen Buddhist spiritual perspective, in denying the ultimacy of involvement or retreat, risks leaving the causal series from which there is no finite escape in a non-teleological state of suspended indifference. ${ }^{88}$ Can escaping the "dualities of here and there, subject and object" be compatible with the engaged middle path between density and relation discussed above $?^{89}$ A similar difficulty might pertain if the via negativa

87 The Edge, pp. 154-5, 156-85. See Masterman, 'Metaphysical and Ideographic Language', p. 300. On the literary significance of ellipsis points, and the link between the rise of their use in the last two hundred years and the thematisation of the fragmentary and incomplete nature of thought, see Anne Toner, Ellipsis in English Literature: Signs of Omission (Cambridge: Cambridge University Press, 2015), especially pp. 151-170.

88 The Edge, pp. 164-5.

89 The Edge, p. 165 
is to be read, according to Denys Turner's asymptotic negation, ${ }^{90}$ by moving beyond either affirmation or denial into an irreducible Weilian attente. ${ }^{91}$ Might the Dionysian mystical path, which transcends kataphasis and apophasis, interpreted by Aquinas as an eminent, negatively qualified projection of the positive, provide an affective non-totalising correlate of waiting? Such a path presumes a bringing-together of ekstasis and absence, impossible to understand or represent, yet experienced or received in time. ${ }^{92}$ Perhaps it is in this way that one might render a difference between a Christian and a Buddhist perspective, since the purpose of the Christian analogical path of ascent is that, within the series of arising entailed realities, there are preferences to be made or affinities to be elected, poetic responses in which particular places and particular words respond to one another's thrall, or are more appropriately linked with particular times or themes. By being reconciled to the impress of these contingences, one seems to draw closer to the transcendent goal, which is not conceived as withdrawn into existential indifference. ${ }^{93}$ Silence is not the last word, but shares penultimacy with utterance, if we are to adhere to their situated character.

90 Denys Turner, The Darkness of God: Negativity in Christian Tradition (Cambridge: Cambridge University Press, 1998).

91 But see Kotva, 'Repetition and Reciprocity', Chapter 4, especially pp. 158-162. Here it is argued that, for Weil, attente is construed in intentional and orientated terms.

92 Timothy D. Knepper, Negating Negation: Against the Apophatic Abandonment of the Dionysian Corpus (Eugene OR: Wipf and Stock, 2014).

93 “As knower and speaker, I must come to terms with finitude, with limit [. . .]". The Edge, p. 108 
Is this to transcend Hegel? This is perhaps a secondary issue in this context. For the somewhat Romantic or even Thomistic Hegel which Williams recommends, after Andrew Shanks and Nicholas Adams, ${ }^{94}$ Hegel can speak in favour of analogy, paradox and the ultimacy of artistic representation. However, for an immanentist 'death of God' reading, such as that of Slavoj Žižek, ${ }^{95}$ the rebounding of absolute, realised intelligence towards the contingent and historical sphere is a dialectical exhaustion of this intelligence in the formal structures of freedom whose content at the end of history will be the randomness of the freely elected.

His reading of Hegel according to the former model indicates how Thomistic, in an extended sense, Williams's frameworks are. ${ }^{96}$ Were this not the case, he might have been tempted, in line with a confined reading of Masterman, to witness to the importance of poetry by translating it into terms which could be fanned and then fed into machine translation, and this would no longer depend upon a truth-maker. ${ }^{97}$ Such a translation,

94 Nicholas Adams, Eclipse of Grace: Divine and Human Action in Hegel (Oxford: Wiley-Blackwell, 2013); Andrew Shanks, A Neo-Hegelian Theology: The God of Greatest Hospitality (Farnham: Ashgate, 2014).

${ }^{95}$ Slavoj Žižek, Less than Nothing: Hegel and the Shadow of Dialectical Materialism (London: Verso, 2012).

${ }^{96}$ The Edge, pp. 186-197.

97 I have argued above that Margaret Masterman's formulation of ideographical language serves as a facility for accommodating the paradoxes of poetry and mediaeval theological statements. The same may be said of her related work on machine translation, which, likewise, may not be at odds with Williams's more Thomistic purposes as outlined in this paragraph. Indeed, when Masterman compares computing with the seventeenth century optical telescope ('Freeing the Mind', Times Literary Supplement 284 (17 April), pp. $23 \mathrm{ff}$ ), she argues that her ideographic technique could extend our perceptual scope and reach, just as the telescope "was a factor in changing [the seventeenth century] picture of the world" (p. 23). As Willard McCarty outlines, she insisted upon its potential for qualitative, and not just quantitative transformation; McCarty, 'A telescope of the Mind?', p. 113. See Masterman's detailed elaboration of the 
one might argue, would risk absolutising the transcendental conditions of poetry, producing not just an epistemological but an ontological transcendentalism, without need of vertical transcendence. Williams does not read the unfinishedness of poetry as suggesting the hypostasised superiority of incompletion, as one might if one were following a Derridean or postmodern-Kantian mode. Rather, what matters is the next monadic word-grouping which has, for now, an anticipatory finality, though we know that this estate will soon enough pass, though with partial exceptions and surprises. The reason for favouring transcendence over the transcendental is that, for such a perspective, transcendence eminently gives the irreplaceable contingent, monadic moments of finite reality their significance.

In the foregoing, I have suggested that language as addition and truth as event restore a realism which points towards a requisite transcendence. This is Williams's argument to God, as we have seen. It involves, as he indicates - with a citation of the work of Douglas Hedley - a participation of being, and of natural and cultural creativity and imagination in the Divine creative Logos. ${ }^{98}$ Yet this invocation, by poetic means, of a traditional realism, somewhat qualifies it, insofar as the transcendental setting for poetry, or the habitual unfolding of natural-cultural reality, cannot sustain the indication of vertical

notion of "philosophical discovery”, 'Metaphysical and Ideographical Language', pp. 283-314, and main text above.

${ }^{98}$ Douglas Hedley, Living Forms of the Imagination (London: T. and T. Clark, 2008). 
transcendence without allowing that new ideographic or monadic instantiations of this setting may qualify our sense or our account of it.

Although he does not elaborate such a point, this would seem to indicate the way for Williams's linguistic metaphysics to presume not only the transcendent God, but also the incarnate God. The Christian revelation is peculiarly in keeping with this philosophy, as Williams does say, since revelation occurs through a speaking personal body engaged with a community which he transforms through that very engagement. This is tantamount to saying that, for Christianity, Christ is the splendid embodied ideograph, of whom the world cannot contain its stories (John 21.25). To spell out Christ's identity, embodied in these stories, "Crying Whát I dó is me: for that I came"," is to spell out his relations with everything else, the "ten thousand places" of Hopkins's 1877 sonnet, ${ }^{100}$ and to do this is to represent, ring, deal out, speak and spell, "find tongue to fling out broad its name" Christ. $^{101}$

But Williams claims to indicate the fittingness of Christian revelation to the scheme of his metaphysical framework, for which God acts at all times through nature. His framework is not overturned insofar as revelation fails to provide all the answers, but rather confirms

${ }^{99}$ G. M. Hopkins, “As kingfishers catch fire”, Poems and Prose W. H. Gardner ed (Harmondsworth: Penguin Books, 1953), p. 51, line 8. See C. J. C. Pickstock, 'The Game of the Stone', Theology 115.3 (2012), pp. 190-197.

${ }^{100}$ Hopkins, “As kingfishers catch fire”, line 12.

101 “As kingfishers catch fire”, line 4; also line 12. 
and intensifies the incompletion of linguistic response. ${ }^{102}$ He seeks to offer "a perspective for which difficulty is what makes sense". ${ }^{103}$

But one might qualify these metaphysically modest statements in two ways. First, it is true, insofar as, in one ideographic direction, to speak and spell Christ's identity requires a framework akin to Augustine's Christus Totus, which is the eschatological, cosmic Church. For now, we struggle our way towards Christ as to God through word, sacrament and deed. And yet, in the opposite ideographic direction, Christians know by faith that this one historic vertex of densities and relations enigmatically contains all the enigmas and all their resolutions, even though these will not resolve in such a way that we could anticipate.

Secondly, it is clear that, for Williams, the revealed God is ontological and saturated, and by no means compressed and ontic. For this reason, one might seek to draw a connection between the fact that the ontological God of philosophical theology and the God of revealed theology are one and the same, and the aporetic tension which seems to arise (and to which Williams is at times commendably subject) between an emphasis upon language as transcendentally incomplete, and a qualifying emphasis upon the monadic reflection of plenitudinous transcendence as in a potential revisionary excess of the transcendental framework. In other words, any poem is in excess of any poetics, and may

102 The Edge, pp. 180-185.

103 The Edge, pp. 180. 
cause us to revise our ideas as to such a poetics. It is for this reason that there cannot be a comprehensive scientific or computerised translation of poetic practice. But if any of the foregoing is correct, one should exalt neither the finished nor the unfinished, as Williams suggests with respect to the Koan and the via negativa, neither the transcendental condition of possibility nor its exemplified instances, and neither poetics nor any particular poem. There is no poem which could lay claim to finality as to content or form. Because of this problem, it might seem that the representation of God must remain restless until both the conditioning factor and the exemplifying factor coincide, as they are taken to do in the Incarnation, Christ being the final and not yet final poem, as well as the framing Logos of poetic principle.

The foregoing suggestions only serve to strengthen Williams's case that the embodied character of Christ is a peculiarly appropriate instance of an expectation of revelation, or of more direct divine disclosure which his linguistic natural theology has opened to view.

Does this same natural theology point towards the Trinity? This would demand a long argument, but one could tentatively suggest that the ordered structure of number, governed by transcendental unity, and discovered at the core of nature, represents a universal finite echo of divine Paternal unity and originating power. Such a model stands in contrast to the transcendental unity taken as random sets, abstracted from the manifold 
void, as for Alain Badiou. ${ }^{104}$ Equally, one could suggest, dilating Williams's thesis that nature speaks, that habitual repetitions which constitute things, together with the habitual relations and boundaries between things, cease - like ellipses or silences - to be but numbers, and become implicitly signs, to the extent that what is related or bounded may be varied or revised in time. The relations and boundaries do not consist in a numerical exactitude of placing, but rather in the judgement of a meaningful character or impress of separation and combination. ${ }^{105}$ In this, we witness a participatory echo of the divine Logos, the symbolic supplement to nature, which, according to Williams, reveals it in adding to it and incompletely completing it. One could add that, insofar as these ellipses and intervals act as further densities and powers, or can be appropriated, one can say that the sign is newly enumerated and assumes the character of gift, which fuses meaning and thing, and which has been taken to characterise the Holy Spirit.

With rising degrees of substantive appropriation and intensity, and of internalised relationality, nature, from the inorganic through to the human, presents this interweaving of number, sign and gift.

${ }^{104}$ Alain Badiou, Being and Event Oliver Feltham tr (London: Continuum, 2005), especially pp. 52-9, 208, 251.

105 The Edge, p. 180; on the intervention of judgement, see Repetition and Identity, pp. 1-83. See further Masterman's ideographical discussion of the "theological paradox [. . . 'God is Three and God is One"”, 'Metaphysical and Ideographic Language', pp. 305-308; also p. 299. 
In God, the tension between density and relation, which prevents horizontal compactness of dominating process, is not collapsed, but intensified in the coincidence of constitutive substantive relation. For this scheme, personified unity is the giving of the word, and both are the proffering of the word as renumbered gift, whereby a thingly density is added again to the transparency of sign. The transcendent plenitude does not sustain a vertical, substantive compactness, which would suppress horizontal event and procedure. Rather, these are eternally given. One might conclude that, in God, for Williams, there is an infinite offering of a representing signifying addition to given numerical being.

It does not seem inappropriate to suggest that Rowan Williams is arguing in The Edge of Words that we need to bring together mathematical and computer sciences with poetics, and all these together with theories of socially constitutive generosity and reciprocity, if we are to begin to approach the Triune as well as the Creator God. We must continue to improvise, speak and offer meaningful words to our neighbours in order to offer our own dilation of the complete Christic poem. 